\title{
The Effectiveness of Historical Documentary Films as Information Technology in Improving Student Learning Outcomes
}

\author{
Maskun $^{1 *}$, Sumargono ${ }^{2}$, Rinaldo Adi Pratama ${ }^{3}$, Albet Maydiantoro ${ }^{4}$ \\ ${ }^{1,2,3,4}$ Faculty of Teacher Training and Education, University of Lampung, \\ Bandar Lampung City, 35141, Indonesia \\ *Corresponding Author: maskun.1959@fkip.unila.ac.id
}

\author{
Received: June 2, 2021. Revised: August 20, 2021. Accepted: August 23, 2021. \\ Published: August 25, 2021.
}

\begin{abstract}
This study aims to determine the effectiveness of documentary film media on the Dutch East Indies colonial history in Indonesia on student learning outcomes. History learning is a crucial subject in shaping students' character and nationalism. Dutch East Indies colonialism is one of the topics in high schools in Indonesia. This study used a quasi-experimental research model involving 35 students in the experimental group and 36 students in the control group, with a nonequivalent pretest-posttest control group configuration in class XI SMA. The data analysis showed that the experimental class score averaged 88.14 and the control class averaged 79 . These findings indicate a substantial difference between the experimental learning outcomes and the control group learning outcomes. Historical documentary film media has been proven to improve student learning outcomes, especially the experimental group. Therefore, historical documentaries are effectively used to increase students' knowledge of history subjects.
\end{abstract}

Keywords-instructional media, documentary films, learning outcomes, history lessons, students.

\section{INTRODUCTION}

$\mathrm{H}$ ISTORY learning in schools aims to make students gain historical thinking skills and historical understanding [1, 2]. Students may acquire skills to think chronologically and know the past through historical development, which can be used to recognize and clarify the development and transition process in culture and socio-cultural diversity to establish and encourage national identity amid community life[3, 4].

History learning is an important subject in shaping students' character and nationalism. One way to form the nation's character is through the study of history. When there are problems in learning history, there are problems related to nationalism. This learning problem refers to theory, lack of imagination, textbook references, country-oriented curricula, and the tendency not to pay attention to the phenomenon of globalization that washes away the historical background [5, 6]. History lessons often take the role of memorization lessons and boring lessons. The learning is nothing more than a numerical sequence of years and events that must be memorized and then revealed again when answering exam questions. This fact cannot be denied because it is still happening today [7-9].

The teacher's professionalism lies not in the ability to develop the knowledge they have, but rather in the ability to carry out exciting and to set and relate to the close learning for students. The subjects' attractiveness is determined by two elements: the subject and the teacher's teaching method. Therefore, the task of a teacher is to deliver the lessons that were previously uninteresting to be interesting, which are considered difficult to be easy. So that learning in the classroom can run according to the teacher's wishes, innovative learning models and media are needed that emphasize students to be more active $[10,11,12]$.

In secondary schools, the teaching and learning method is decided not only by the teacher but also by learning means and student activities. In the 21 st century, technological advances allow children to grow naturally into a broader range of access to knowledge $[13,14]$. ICT improves constructive learning and growth practices $[15,16]$. There is already a transition in world education in many countries to more immersive, enjoyable, and experiential teaching methods [17]. Professors are expected to be able to use accessible media in classrooms. ICT should follow a sound pedagogic approach $[18,19]$. Professors are expected to be able to use accessible media in classrooms. ICT should follow a sound pedagogic approach [18, 19]. The research process began to change from an instructor as a primary curriculum source to a teacher as a research facilitator in the classroom.

The development of teacher skills and efficiency starts in all human life fields, including schooling, modern knowledge, and communications technologies (ITC) [20, 21]. The school 
system plays a significant role in creating a society, and the impact of early childhood education can support the acquisition of knowledge [22, 23]. Teaching aims at encouraging people to read and learn through working time. The presence of community education will develop awareness and expertise to improve residents' and society's welfare.

Students were educated as objects so far. Students' awareness is ready, but it is not easy to step through a mechanism that must be formed, considered, and built caused by students only passively involved. An instructor should hold students' interests in studying, studying, and developing enthusiasm to learn, learning the first lessons of their school life, and enjoying learning [24, 25]. Exciting and close learning settings must be created to actively help students' activities in the learning [26, 27]. For those reasons, the education program's consistency becomes the foundation of learning life. It should also concentrate on real-life issues [28].

The lowest learning outcomes in school are often indicated by these students' learning problems in understanding the material. This indication occurs due to ineffective student learning factors. Sometimes, even students themselves are less motivated to participate in class learning, which causes them to understand less or understand the subject matter given. Good learning can be supported by a conducive learning atmosphere, and the relationship between teachers and students can run well [29-32].

A teacher should make an effort to solve these problems. One of the solutions in educational media use can significantly contribute to the success of the learning process and the teacher's delivery of messages and the information content [33]. Learning media is a tool used during the learning process, which helps teachers deliver material to students [34]. Teachers can use the learning media in the learning process, for example, cassettes, videos, computers, CDs, films, documentary films, and others. One of the interesting is documentary film learning media usage to teach the history subject [35].

The films have advantages for both students and teachers. The film is excellent because it can explain a process. Historical films can depict past events realistically in a short time [36]. The use of film media in learning provides many benefits for learning, such as students can more accept the teaching contents easily, and students will be more motivated to learn. The historical film media can give an attractive impression to students and foster students' national spirit. Documentary film learning media has advantages, namely to teachers who can display moving visuals, both in color and in black and white, that contain learning material, can create unique visual effects that can make the learning process more attractive [37, 38]. More specifically, for the topic is history Documentary Film usage.

Documentary film learning media used for history learning in high schools include the Dutch Indies Colonial History Documentary Film. The material on the history of the Dutch East Indies colonialism is history subject matter at the high school level. Also, through the Dutch Indies Colonial History Documentary Film, students can identify the essence of life in an area with the virtues and characteristics of the area where they live so that their understanding of the history of the area gets better. Undoubtedly, the Dutch colonization of documentary film is used as an alternative for resolving the problem of learning in the history class, according to the description above. So, this researcher formulates a hypothesis, namely:

H0: Students whose learning uses historical documentary film media as effectively as group students without using historical documentary film media.

H1: Students who use historical documentary film media in their learning process are more effective than students who do not use historical documentary film media.

\section{LITERATURE REVIEW}

\section{History Learning}

Historical learning notes that it is a mixture of learning and teaching practices in which historical events that are closely connected to the present are taught [35, 39]. Good history learning is learning that can foster students' abilities by constructing present conditions by linking or seeing the past, which is the basis of history learning topics [40-42]. This opinion is in line with understanding history from the time's point of view. There are three-time frames in understanding history: short term, midterm/medium-term, and long term. History is also discussed from a spatial perspective that cannot be ignored [43]. Students must understand the concept of changing time in history learning and realize it [44-46]. It is also possible to pay attention to contemporary developments that are increasingly global in history learning to become a vehicle for developing intellectual abilities and pride in the past and efforts to improve people's lives in the fields of socio-economic politics and culture.

Learning history is a gate for learning about what happened and its lessons. Learning history, in all its ways, is learning about humanity. The purpose of studying history is to make someone wise. Learning history would give rise to an understanding of the essence of human culture and civilization's creation, which is then referred to as historical awareness (historical awareness). Therefore, one purpose of studying history is to build historical knowledge. The learning history process in schools must also look at creating circumstances that can build historical knowledge[47, 48].

\section{Documentary Film}

To create a significant impact on the learning process, history learning in schools requires learning media. Learning media is a set of resources or supplements that teachers or educators use to engage with learners [49-51]. Good learning media can help students provide feedback and feedback and encourage students to carry out correct practices. Learning media consists of several forms, one of which is film documentary media. A documentary film is one type of film which is an actual, creative report based on information [52-54], by the statement of [55], from factual events that occur and basic patterns in documentary films describing the problems of human life.

Movies can be divided based on duration, namely, 1). Short films are with duration of under 60 minutes, 2). Long films that are over 60 minutes long [56-58]. Meanwhile, the film is divided into 4, fiction films, animated films, experimental films, and documentary films. One type of film that teenagers love producing is a documentary film $[59,60]$. In recent years' 
documentary films have become prestigious events for Indonesian youth, so many documentary films events and festivals have been held at the student, student, and public levels. This is also between schools, colleges, and prestigious national-level film events involving Indonesia's young generation. When viewed from the theme raised in every event or festival held in Indonesia, it focuses more on cultural and educational themes. It is most likely based on Government Regulation of the Republic of Indonesia number 23 of 1999 concerning the Implementation of Handover and Management of Recorded Films or Films. In this regulation, the fact that the work of recording story films or documentary films in frogs is one of the nation's artistic works as a manifestation of creativity, taste, and human initiative and has a critical role in supporting development in general, development education, research, development of knowledge and technology and dissemination $[61,62]$.

One of the documentary films is about the colonization of the Dutch East Indies in the Lampung region. The use of historical documentary films by teachers will impact helping students obtain an overview of the events. The historical process of the Dutch East Indies colonization in Lampung occurred in the past, which was unlikely to be encountered by students in their time. However, students can see a chronological sequence as desired in the learning process through the documentary films. Students will also be able to see objects of historical relics [63, 64]. It looks like it is natural in front of them because documentary films are audio-visual. The use of documentary films will add material for historical learning media in schools [65-68]. Students will be happy and interested in taking history lessons, so it is not surprising that students look enthusiastic about watching historical documentaries.

\section{Learning Outcomes}

The most significant portion of learning is learning outcomes. [69-72] Describes student learning outcomes as improvements resulting from learning that encompasses the cognitive, affective, and psychomotor fields in a broader context. [73-75] Also, note that the product of an association of learning actions and actions is learning outcomes. The teaching act finishes with a method of measuring learning performance from the teacher's hand. Learning results stop at the peak of the learning process from the student side. Six styles of cognitive conduct are stated by [76], namely: a) The ability to recall items, b) Comprehension, c) Involves the use of techniques and laws to deal with real and new problems, d.) Analysis, e) Synthesis, and f) Assessment.

Good learning will produce quality education [77]. So that teachers must be able to make every effort in preparing learning tools with lesson plans, teaching materials, learning media, and learning evaluation [78, 79]. One of these crucial things is realized by using learning media for students, which is applied in the classroom. Therefore, historical documentary film media in history is an alternative [80-82].

\section{METHODOLOGY}

\section{Research Model}

This research uses a quasi-experimental design that uses the nonequivalent design paradigm of a control group [83]. As seen in the following table, the design of this analysis is:

Table I. Experimental Design

\begin{tabular}{lccc}
\hline Category & Pretest & Treatment & Posttest \\
\hline $\begin{array}{c}\text { Experiment } \\
\text { Class }\end{array}$ & $\mathrm{O}_{1}$ & $\mathrm{X}_{1}$ & $\mathrm{O}_{2}$ \\
\hline Control Class & $\mathrm{O}_{3}$ & $\mathrm{X}_{2}$ & $\mathrm{O}_{4}$ \\
Information: & & \\
O1: Pretest in the experimental class \\
O2: Posttest in the experimental class \\
O3: Pretest in the control class \\
O4: Posttest on the control class \\
X1: Treatment with documentary film media \\
X2: Treatment with conventional media
\end{tabular}

\section{Sampling and Data Collection}

This study's population was Class XI SMA N 1 Natar Lampung Selatan students. This school has a homogeneous population and has the same potential, so the survey was carried out using purposeful sampling techniques in this research, namely 36 XI IPS 1 students as an experimental class and 35 XI IPS 2 students as a control class. The research was conducted at SMAN 1 Natar during the first semester of the 2020/2021 academic year, when the research was carried out.

\section{Data Collection Instruments}

The form of a multiple-choice test instrument with 50 items, five answer choices, one correct answer choice is given a value of 1 , and the wrong answer choices are given a value of 0 . The item validity test is carried out by displaying Pearson's Product Moment. The product moments confidence level between the item and item scores is > based on the table based on the Pearson Product Moment $r$ table at the alpha significance level $=0.05$. Only items that are empirically declared valid and meet the requirements are then compiled as a research instrument. The calculation of the instrument's reliability in this study used KR20, a test used to answer true and false (dichotomy) about the material of history. In practice, the test score given is 1 for respondents who answered correctly and 0 for respondents who answered incorrectly.

\section{Data analysis}

Analysis, namely descriptive analysis, and differential analysis are used in this study. The authors did display the distribution table, histogram, mean and standard deviation, descriptive analysis. Hypothesis testing was carried out with the two-tailed (2-tailed) Mann-Whitney $U$ review test with a substantial level of alpha $=0.05$ using the SPPS 16 assistance software. The specifications test was performed in a normality test and a homogeneity test before the Mann-Whitney test.

There is a standard distribution of the normality test to see details on student learning outcomes in each category. The Kolmogorov-Smirnov test was used in the normality test in this analysis. This test criterion usually distributes the data with a significance value $>\mathrm{a}=0.05$. History homogeneity test about whether the data on learning outcomes between groups are homogeneous. The homogeneity test in this study used the Levine test. With this criterion with a significance value $>\alpha=$ 0.05 , the data can be homogeneous. 


\section{FINDINGS AND RESULT}

\section{Current learning process}

In this analysis, the place of testing was in two groups, namely SMA N 1 Natar Lampung, with class XI students as the focus of this study. Preliminary research was carried out to collect preliminary evidence on the circumstances about the use of learning media. The preliminary research gathers information on realistic learning practices, school-based facilities and resources, and the outcomes achieved during the lesson.

The teacher often prefers using learning media-based only based on the interviews' outcomes. The most important thing is to learn to walk as usual. The facilities at school, including usability of LCD projectors and laptop schools, are ideal for implementing the learning media in groups. The teacher, however, is vague and lacks enthusiasm for developing a creative process of learning that is different from usual. (a) the teaching aids were written by the lecturer on the blackboard also prioritize the instructor over conventional media, the results of a preliminary review of one of the class learning activities in the history subject. It became a problem in learning because it was found that many students still misinterpreted and did not understand the history of colonization in Indonesia. Also, when the teacher draws on the blackboard, students ignore the teacher; some play, joke with friends, and even run in groups. It gets worse when the teacher says nobody pays attention and requires the students. There is ample time for the teacher to write on the blackboard so that pupils get distracted and get more interested outside school; (b) the teacher's learning has not been accomplished because only basic theory and teaching aids in interpreting the theory are provided students. Students are at least puzzled, bored, and even uninterested in connecting between subject matter and real-life. Students will attempt to link the content itself with the understanding they have previously gained. Consequently, learning becomes passive, and in groups, learners appear to remain silent; (c) teachercentered. Because learning so far has made students only listen to the teacher's explanation, this has resulted in students not focusing on the teacher.

The main factor of the many problems, such as (a) lack of student motivation, is believed to result from early learning. In interacting with learning media that are of interest to students, the lecture approach will make students not interested in deeper learning. However, if the teacher simultaneously uses most of the techniques used and teaching aids, In the lessons presented, the students will become bored and unselfish; (b) they will not focus on the lesson. During class, the action is seen. When the teacher explains a crowd of students who want to do things out of study activities in forepart. (c) Lack of understanding of the interpretations given by the teacher. Students become confused by the many historical lines in the colonial content that is memorized and memorized. On the test results, most students scored below the passing grade. The lack of detailed examples and media for presentations will make it easy for students to do activities outside of their classroom. Their results are not only focused on learning which makes the students less conscious of learning.

Financing for the use of learning media is sufficient in terms of equipment and resources in classrooms. There are many options for finding and accessing learning media. However, information technology skills are essential for learning in schools, especially by senior teachers. Also, senior teachers' attitude who use the lecture method to learn information technology is more comfortable and relaxed. Finally, informative and summative tests, the teacher confuses students' learning outcomes at lower graduation levels. From the document review results, in the history subject, the subject of Dutch Indies colonization, 24 people passed, while 47 others did not meet the grades. It is a big concern in the community teaching and learning process.

\section{Pretest Data of Experimental Class}

The experimental class uses historical media to make documentary films. Before the researcher received the therapy, the study sample was given a pretest (treatment). Thirty-six students who were given fifty multiple-choice questions were the sample used to take part in the pretest.

Table II: Experiment class pretest value

\begin{tabular}{cccc}
\hline Mean & Median & Modus & $\begin{array}{c}\text { Standard } \\
\text { Deviation }\end{array}$ \\
\hline 67,19 & 66,00 & 66,00 & 4,82 \\
\hline
\end{tabular}

The pretest results' mean value is 67.19 , the median is 66.00 , the modus is 66.00 , and the average variance is 4.82 . Table 2 shows the mean value of the pretest results. It is understood that the typical test class does not satisfy the requirements that have passed. Treatment can then be performed to raise and meet the specified passing criteria by the average performance of the experimental group of students. A summary of the experimental community findings is given in the following table:

Table III: Experiment class pretest value

\begin{tabular}{cccc}
\hline No & Interval & Frequency & $\mathbf{( \% )}$ \\
\hline 1 & $76-85$ & 3 & 8,33 \\
2 & $66-75$ & 22 & 61,11 \\
3 & $56-65$ & 11 & 30,56 \\
\hline Total & & $\mathbf{3 6}$ & $\mathbf{1 0 0}$ \\
\hline
\end{tabular}

Table III indicates a score of 85 is the highest and a score of 56 is the lowest. The value was generally seen in the interval group of 66-75, and the incidence frequency in the interval group of 76-85 was rare.

\section{Control Class Pretest Data}

A monitoring group is a group not handled by historical film media. In other words, learning is using conventional media. A pretest was also given to the control group prior to treatment. The preliminary research sample contained 36 students. Fifty multiple-choice questions were then asked.

Table IV: Control class pretest grade

\begin{tabular}{cccc} 
Mean & Median & Modus & St. Dev \\
65,83 & 66,00 & 63,00 & 5,46 \\
\hline
\end{tabular}

Table IV reveals that the average value is 65.83 for a pretest control package, the average value is 66.00, the modus at 63.00, and the default is 5.46. This means that the control type means, 
as in the experimental category, do not follow the passing criterion. A summary of the experimental community findings is given in the following table:

Table V: Control class pretest value

\begin{tabular}{cccc}
\hline No & Interval & Frequency & $\mathbf{( \% )}$ \\
\hline 1 & $76-85$ & 2 & 5,71 \\
2 & $66-75$ & 16 & 45,71 \\
3 & $56-65$ & 16 & 45,71 \\
4 & $45-55$ & 1 & 2,86 \\
\hline Total & & $\mathbf{3 5}$ & $\mathbf{1 0 0}$ \\
\hline
\end{tabular}

Table V shows the students' highest score of 85 , while the lowest score is 45 . The most frequent scores were in the intervals of 66-75 and 56-65, while the frequency was rarely in the 45-55 interval.

\section{Experiment Class Posttest Data}

The study group was then given a posttest after undergoing a learning therapy using historical documentary video media. The findings after the exam are the product of the student's final learning. A total of 50 multi-choice questions answer the questions.

Table VI: Experiment class posttest value

\begin{tabular}{cccc}
\hline Mean & Median & Modus & St. Dev \\
\hline 88,14 & 88 & 85 & 5,35 \\
\hline
\end{tabular}

Table VI indicates an average value of 88.14 for the pretested control sample, 88 modes 85 for the median, and 5.35 for the normal variance. This illustrates that the typical test class fulfils the requirements. Table 7 below summarises the findings of the pre-research test group:

Table VII: Experiment class posttest value

\begin{tabular}{cccc}
\hline No & Interval & Frequency & $(\boldsymbol{\%})$ \\
\hline 1 & $90-97$ & 8 & 22,22 \\
2 & $82-89$ & 22 & 61,11 \\
3 & $74-81$ & 6 & 16,67 \\
\hline Total & & $\mathbf{3 6}$ & $\mathbf{1 0 0}$ \\
\hline
\end{tabular}

Table VII shows the students' highest score of 97, while the lowest score is 74. The most frequent scores were in the intervals of 82-89 interval groups, while the frequency value of their appearance was rarely found in the 74-81 interval groups.

\section{Control Class Posttest Data}

After receiving learning treatment without the use of historical documentary film media, the control class performed a posttest. The posttest result results from the student's final study achievement. The questions asked are fifty multiple choices.

Table VIII: Control class posttest value

\begin{tabular}{cccc}
\hline Mean & Median & Modus & $\begin{array}{c}\text { Standard } \\
\text { Deviation }\end{array}$ \\
\hline 79,00 & 78,00 & 73,00 & 5,02 \\
\hline
\end{tabular}

Table VIII reveals a mean value of 79.00 , a median value of 78.00 , mode 73.00 for the pretest control group, and a standard deviation of 5.02. This indicates that the control sample did not meet the expectations for graduation on average.

Table IX: Control class posttest value

\begin{tabular}{cccc}
\hline No & Interval & Frequency & $(\boldsymbol{\%})$ \\
\hline 1 & $85-92$ & 4 & 11,43 \\
2 & $77-84$ & 20 & 57,14 \\
3 & $69-76$ & 10 & 28,57 \\
4 & $51-58$ & 1 & 2,86 \\
\hline Total & & $\mathbf{3 5}$ & $\mathbf{1 0 0}$ \\
\hline
\end{tabular}

Table IX shows the students' highest score of 92, while the lowest score is 51 . The most frequent scores were in the intervals of 77-84 interval groups, whereas the frequency of occurrence was rarely in the 51-58 interval group.

\section{Hypothesis-testing}

Testing the research hypothesis was tested by using the Independent T-test by doing the prerequisite test first. To see the final state after being given treatment (between experiment and control), a posttest was given to two groups of subjects who were given different treatments, namely learning media. Hypothesis testing in this study uses the t-test.

Table X: Hypothesis Test Results

\begin{tabular}{|c|c|c|c|c|c|c|c|c|c|c|}
\hline & & $\begin{array}{l}\text { Leven } \\
\text { for } \mathrm{E} \\
\text { of } \mathrm{Va}\end{array}$ & $\begin{array}{l}\text { Test } \\
\text { ality } \\
\text { inces }\end{array}$ & \multicolumn{7}{|c|}{ t-test for Equality of Means } \\
\hline & & \multirow[t]{2}{*}{$\mathrm{F}$} & \multirow[t]{2}{*}{ Sig. } & \multirow[t]{2}{*}{$\mathrm{t}$} & \multirow[t]{2}{*}{ df } & \multirow[t]{2}{*}{ Sig. (2-tailed } & \multirow[t]{2}{*}{$\begin{array}{c}\text { Mean } \\
\text { Difference }\end{array}$} & \multirow[t]{2}{*}{$\begin{array}{l}\text { Std. Error } \\
\text { Difference }\end{array}$} & $\begin{array}{r}95 \% \mathrm{C} \\
\text { Inter } \\
\text { Dif }\end{array}$ & $\begin{array}{l}\text { fidence } \\
\text { lof the } \\
\text { ence }\end{array}$ \\
\hline & & & & & & & & & Lower & Upper \\
\hline \multirow[t]{2}{*}{ Posttest } & $\begin{array}{l}\text { Equal variances } \\
\text { assumed }\end{array}$ & .045 & .833 & 7.313 & 69 & .000 & 9.13889 & 1.24968 & 6.64585 & 11.63193 \\
\hline & $\begin{array}{l}\text { Equal variances } \\
\text { not assumed }\end{array}$ & & & 7.320 & 68.917 & .000 & 9.13889 & 1.24855 & 6.64804 & 11.62973 \\
\hline
\end{tabular}

It is known that the learning outcomes by SPSS 16 are significant at $0.000<0.05$, so that $\mathrm{H} 0$ is rejected and $\mathrm{H} 1$ is accepted. It indicates that there is a significant difference between the experimental class and the control class after treatment. Because the average value of the history learning outcomes of the experimental class (the group using the historical documentary film learning media) $=88,138>$ the average score of the history learning outcomes of the control class (the group using traditional media) $=79$, it can be proven that the results of learning history using historical documentary film learning media is higher than history learning using conventional media. 


\section{DISCUSSION}

In this analysis, the effect of historical documentaries on historical outputs of learning is established and empirically illustrated. This study indicates that alternative media are needed to help students study topics in history. Based on the issues posed by the description above, learning findings vary between the experimental class in historical documentary media and the control class in typical media and the efficiency of using historical documentary films in high schools. After the hypothesis checking, the study found that $\mathrm{H} 0$ was rejected and H1 was accepted, indicating that using historical movie documentary media by experimental classes yielded significant learning effects.

Therefore, the experimental group using historical documentary film media in class XI SMA historical learning obtained better results than the control group. The control group had an overall average posttest score of 78 . The most significant improvement in the experiment group is an increase in the pretest outcomes of all participants. The experimental group increased by 20.81 , and the control group increased by 12.17 .

It indicates a significant impact on the study community results in higher proportions on those who utilize Historical Documentary Film. Therefore, history should be disputed that documentary film media are more powerful than traditional media learning. Therefore, the fact is that the students who learn to use historical film media become more successful than those who do not use historical documentary film media. These findings support $[84,85]$ - analysis suggesting that the media employed will preferably affect the correct media' muse. The used video must be acceptable for the pupil. To make the content conveyed by video media easier for students to understand.

The nature of documenter videos makes the abstract content more accessible for students to grasp. Documentary films will allow students to appreciate the subjects discussed [86-88]. Documentary videos are a better experience for students as alternative media. Videos can significantly inspire and draw student interest if enriched with multimedia (images, animation, music, sound) [89, 90]. This is also in line with [91-93] analysis, making studying history more exciting and enjoyable by using film documentation. This film style aims to assess the depth of understanding of the students' content so the video can be played back. Video in this study is seen in history as an area of science. The study which may be required may be extended to other fields, such as anthropology and sociology.

Experimental findings indicate that students who use historical documentary films receive more fantastic learning results than textbooks. The students are engaged more because the presented documentary does not make learning monotonous [94]. Besides the material in the video that mixes the material with life in the past, the student's reasoning abilities would be defeated by the material in the video.

Documentation papers have become more efficient for statistical imaging in learning factual and logical details and cognitive tasks, including recall, interpretation, and execution, as seen by the meta-analysis findings [95]. The above analysis findings are also endorsed, depending on the results of the hypothesis performed in this report.

\section{CONCLUSION}

This research explores the use of enhanced learning performance in historical documentary film media. The findings suggest that the media for documentary film history has significantly affected the experimental community on student achievement. The student experimental team was more involved and focused on learning. They also enhance the comprehension of the content by comparing everyday life to allow students to appreciate their knowledge and grow it optimally. The improvement in students' learning output has improved dramatically by the control group. Teachers should use historical film media or other media events in the classroom to establish successful learning methods.

Historical media documentaries may be used to overcome textbook (print) and other media constraints. It is shown by using historic documentary media with higher learning performance than using historical film media. While historical documentary film media has a positive effect, it should be noted that educational media has to be focused on the learning needs of students. It must be done for students to use historical documentary films massively.

\section{LIMITATION}

The research examined only the effect of historical films on knowledge aspects while other aspects of learning, such as skills and attitudes, are used for learning. The created learning media are expressly incorporated sub-contexts to further research, the happiness of consumers, and other possible obstacles to using historical records so that the importance and environment of other participants can also be studied.

\section{ACKNOWLEDGMENTS}

The authors would like to thank the Faculty of Teacher Training and Education, Institute for Research and Community Service, University of Lampung, and SMA N 1 Natar Lampung Selatan.

\section{References}

[1] P. Seixas, "Historical consciousness and historical thinking," in Palgrave handbook of research in historical culture and education: Springer, 2017, pp. 59-72.

[2] V. Aidinopoulou and D. Sampson, "An action research study from implementing the flipped classroom model in primary school history teaching and learning," Journal of Educational Technology \& Society, vol. 20, no. 1, pp. 237-247, 2017.

[3] F. Ceschin and I. Gaziulusoy, "Evolution of design for sustainability: From product design to design for system innovations and transitions," Design studies, vol. 47, pp. 118-163, 2016.

[4] V. Popov et al., "Effects of an interculturally enriched collaboration script on student attitudes, behavior, and learning performance in a CSCL environment," Learning, Culture and Social Interaction, vol. 21, pp. 100-123, 2019.

[5] F. Grenier and J. Hagmann, "Sites of knowledge (re-) production: toward an institutional sociology of international relations scholarship," International Studies Review, vol. 18, no. 2, pp. 333-365, 2016.

[6] S. Xu, School leadership, citizenship education and politics in China: Experiences from junior secondary schools in Shanghai. Springer, 2016.

[7] K. Hirsh-Pasek, J. M. Zosh, R. M. Golinkoff, J. H. Gray, M. B. Robb, and J. Kaufman, "Putting education in "educational" apps: Lessons from the science of learning," Psychological Science in the Public Interest, vol. 16, no. 1, pp. 3-34, 2015. 
[8] M. Akbulut and M. Açikalin, "Rebuilding the past through dusty stuff: How Turkish students respond to primary source based social studies education?," Journal of International Social Studies, vol. 10, no. 3, pp. 3-39, 2020.

[9] J. Nottingham, Challenging learning: Theory, effective practice and lesson ideas to create optimal learning in the classroom. Routledge, 2015.

[10] H. Husni, "The Effect of Inquiry-based Learning on Religious Subjects Learning Activities: An Experimental Study in High Schools," Jurnal Penelitian Pendidikan Islam, vol. 8, no. 1, pp. 43-54, 2020.

[11] J. Hyun, R. Ediger, and D. Lee, "Students' Satisfaction on Their Learning Process in Active Learning and Traditional Classrooms," International Journal of Teaching and Learning in Higher Education, vol. 29, no. 1, pp. 108-118, 2017.

[12] L. Bürgener and M. Barth, "Sustainability competencies in teacher education: Making teacher education count in everyday school practice," Journal of Cleaner Production, vol. 174, pp. 821-826, 2018

[13] M. C. Inhorn and P. Patrizio, "Infertility around the globe: new thinking on gender, reproductive technologies and global movements in the $21 \mathrm{st}$ century," Human reproduction update, vol. 21, no. 4, pp. 411-426, 2015.

[14] S. K. W. Chu, R. B. Reynolds, N. J. Tavares, M. Notari, and C. W. Y. Lee, 21st century skills development through inquiry-based learning from theory to practice. Springer, 2021.

[15] D. Alt, "Science teachers' conceptions of teaching and learning, ICT efficacy, ICT professional development and ICT practices enacted in their classrooms," Teaching and Teacher Education, vol. 73, pp. 141$150,2018$.

[16] N. Duţă and O. Martínez-Rivera, "Between theory and practice: the importance of ICT in Higher Education as a tool for collaborative learning," Procedia-Social and Behavioral Sciences, vol. 180, pp. 14661473, 2015.

[17] R. B. Stevenson, M. Lasen, J.-A. Ferreira, and J. Davis, "Approaches to embedding sustainability in teacher education: A synthesis of the literature," Teaching and Teacher Education, vol. 63, pp. 405-417, 2017.

[18] A. Baroutsis, G. McGregor, and M. Mills, "Pedagogic voice: Student voice in teaching and engagement pedagogies," Pedagogy, Culture \& Society, vol. 24, no. 1, pp. 123-140, 2016.

[19] A. S. Canagarajah, "'Blessed in my own way:" Pedagogical affordances for dialogical voice construction in multilingual student writing," Journal of Second Language Writing, vol. 27, pp. 122-139, 2015.

[20] S. Wang, N. V. Gorbunova, A. R. Masalimova, J. Bírová, and M. G. Sergeeva, "Formation of academic mobility of future foreign language teachers by means of media education technologies," Eurasia Journal of Mathematics, Science and Technology Education, vol. 14, no. 3, pp. 959976, 2017.

[21] S. Ghavifekr and W. A. W. Rosdy, "Teaching and learning with technology: Effectiveness of ICT integration in schools," International Journal of Research in Education and Science, vol. 1, no. 2, pp. 175-191, 2015.

[22] C. E. Domitrovich, J. A. Durlak, K. C. Staley, and R. P. Weissberg, "Social- emotional competence: An essential factor for promoting positive adjustment and reducing risk in school children," Child development, vol. 88, no. 2, pp. 408-416, 2017.

[23] H. Hamidi and A. Chavoshi, "Analysis of the essential factors for the adoption of mobile learning in higher education: A case study of students of the University of Technology," Telematics and Informatics, vol. 35, no. 4, pp. 1053-1070, 2018

[24] M. M. Keller, A. W. Hoy, T. Goetz, and A. C. Frenzel, "Teacher enthusiasm: Reviewing and redefining a complex construct," Educational Psychology Review, vol. 28, no. 4, pp. 743-769, 2016.

[25] A. D. Rowe, J. Fitness, and L. N. Wood, "University student and lecturer perceptions of positive emotions in learning," International Journal of Qualitative Studies in Education, vol. 28, no. 1, pp. 1-20, 2015.

[26] H. Tobar-Muñoz, S. Baldiris, and R. Fabregat, "Augmented reality game-based learning: Enriching students' experience during reading comprehension activities," Journal of Educational Computing Research, vol. 55, no. 7, pp. 901-936, 2017

[27] S.-J. Lu and Y.-C. Liu, "Integrating augmented reality technology to enhance children's learning in marine education," Environmental Education Research, vol. 21, no. 4, pp. 525-541, 2015.

[28] A. Fayolle, "Personal views on the future of entrepreneurship education," in A research agenda for entrepreneurship education: Edward Elgar Publishing, 2018.

[29] M. Puteh, C. N. Che Ahmad, N. Mohamed Noh, M. Adnan, and M. H. Ibrahim, "The classroom physical environment and its relation to teaching and learning comfort level," International Journal of Social Science and Humanity, vol. 5, no. 3, pp. 237-240, 2015.

[30] A. Tharani, Y. Husain, and I. Warwick, "Learning environment and emotional well-being: A qualitative study of undergraduate nursing students," Nurse education today, vol. 59, pp. 82-87, 2017.

[31] O. A. Sogunro, "Motivating factors for adult learners in higher education," International Journal of Higher Education, vol. 4, no. 1, pp. $22-37,2015$

[32] S. Papadakis and M. Kalogiannakis, "Using gamification for supporting an introductory programming course. the case of classcraft in a secondary education classroom," in Interactivity, game creation, design, learning, and innovation: Springer, 2017, pp. 366-375.

[33] J. E. Lawrence and U. A. Tar, "Factors that influence teachers' adoption and integration of ICT in teaching/learning process," Educational Media International, vol. 55, no. 1, pp. 79-105, 2018.

[34] S. A. Widodo, "Selection of Learning Media Mathematics for Junior School Students," Turkish Online Journal of Educational TechnologyTOJET, vol. 17, no. 1, pp. 154-160, 2018.

[35] P. Baepler, J. Walker, D. C. Brooks, K. Saichaie, and C. I. Petersen, A guide to teaching in the active learning classroom: History, research, and practice. Stylus Publishing, LLC, 2016.

[36] R. A. Rosenstone, History on film/film on history. Routledge, 2017.

[37] T. Redmond, "Media literacy is common sense: Bridging Common Core Standards with the media experiences of digital learners: Findings from a case study highlight the benefits of an integrated model of literacy, thereby illustrating the relevance and accessibility of media literacy education," Middle School Journal, vol. 46, no. 3, pp. 10-17, 2015.

[38] D. Mardiana and D. C. Anggraini, "The effectiveness of utilising weblearning media towards islamic education learning (PAI) outcome in the era of industrial revolution 4.0," International Journal of Innovation, Creativity and Change, vol. 8, no. 1, pp. 80-96, 2019.

[39] C. Redington, Can theatre teach?: An historical and evaluative analysis of theatre in education. Elsevier, 2016.

[40] G. L. Stoel, J. Van Drie, and C. Van Boxtel, "Teaching towards historical expertise. Developing a pedagogy for fostering causal reasoning in history," Journal of Curriculum Studies, vol. 47, no. 1, pp. 49-76, 2015.

[41] G. L. Stoel, J. P. van Drie, and C. A. Van Boxtel, "The effects of explicit teaching of strategies, second-order concepts, and epistemological underpinnings on students' ability to reason causally in history," Journal of Educational Psychology, vol. 109, no. 3, p. 321, 2017.

[42] K. Nordgren and M. Johansson, "Intercultural historical learning: A conceptual framework," Journal of Curriculum Studies, vol. 47, no. 1, pp. 1-25, 2015.

[43] O. Cullmann, Christ and time: The primitive Christian conception of time and history. Wipf and Stock Publishers, 2018.

[44] G. F. Mrathuzina, A. R. Fayzullina, and F. A. Saglam, "Substantive, methodological and organizational discourse in oriental history learning at school and university," Rev. Eur. Stud., vol. 7, p. 57, 2015.

[45] H. Hastuti, Z. Zafri, and Z. Asri, "Innovation of History Learning through Comic," International Journal of Advances in Social and Economics, vol. 2, no. 2, 2020.

[46] E. Istiyono, W. S. B. Dwandaru, R. Setiawan, and I. Megawati, "Developing of Computerized Adaptive Testing to Measure Physics Higher Order Thinking Skills of Senior High School Students and Its Feasibility of Use," European Journal of Educational Research, vol. 9, no. 1, pp. 91-101, 2020.

[47] L. Jordanova, History in practice. Bloomsbury Publishing, 2019.

[48] U. Nafiáh, M. Mashuri, and D. N. Wijaya, "The Development of Digital Book of European History to Shape the Students' Democratic Values," International Journal of Emerging Technologies in Learning (iJET), vol. 14 , no. 6, pp. 147-154, 2019.

[49] U. Matzat and E. Vrieling, "Self-regulated learning and social media-a 'natural alliance'? Evidence on students' self-regulation of learning, social media use, and student-teacher relationship," Learning, Media and Technology, vol. 41, no. 1, pp. 73-99, 2016.

[50] S. I. De Freitas, J. Morgan, and D. Gibson, "Will MOOCs transform learning and teaching in higher education? Engagement and course retention in online learning provision," British journal of educational technology, vol. 46, no. 3, pp. 455-471, 2015.

[51] F. R. d. Cunha Jr, C. van Kruistum, and B. van Oers, "Teachers and Facebook: using online groups to improve students' communication and engagement in education," Communication Teacher, vol. 30, no. 4, pp. 228-241, 2016 
[52] R. Van Munster and C. Sylvest, "Documenting international relations: Documentary film and the creative arrangement of perceptibility," International Studies Perspectives, vol. 16, no. 3, pp. 229-245, 2015.

[53] A. Goldson, "Journalism plus? The resurgence of creative documentary," Pacific Journalism Review, vol. 21, no. 2, pp. 86-98, 2015.

[54] A. S. Hapsari and M. Hanif, "Motion Graphic Animation Videos to Improve the Learning Outcomes of Elementary School Students," European Journal of Educational Research, vol. 8, no. 4, pp. 1245-1255, 2019.

[55] J. Diesner, R. Rezapour, and M. Jiang, "Assessing public awareness of social justice documentary films based on news coverage versus social media," Conference 2016 Proceedings, 2016.

[56] X. Yang, X. Zhong, J. Zhang, and J. Gu, "Intrinsic high thermal conductive liquid crystal epoxy film simultaneously combining with excellent intrinsic self-healing performance," Journal of Materials Science \& Technology, vol. 68, pp. 209-215, 2021.

[57] S. Chen, M. E. Warwick, and R. Binions, "Effects of film thickness and thermal treatment on the structural and opto-electronic properties of Gadoped $\mathrm{ZnO}$ films deposited by sol-gel method," Solar Energy Materials and Solar Cells, vol. 137, pp. 202-209, 2015.

[58] H. A. Macleod, Thin-film optical filters. CRC press, 2017.

[59] B. Winston, G. Vanstone, and W. Chi, The act of documenting: documentary film in the 21 st century. Bloomsbury Publishing USA, 2017.

[60] S. B. Plate, Religion and Film: Cinema and the Re-creation of the World. Columbia University Press, 2017.

[61] J. Hartley, Communication, cultural and media studies: The key concepts. Routledge, 2019.

[62] M. Chanan, Politics of documentary. Bloomsbury Publishing, 2019.

[63] D. Lee, Activist archives: Youth culture and the political past in Indonesia. Duke University Press, 2016.

[64] G. Saad, Variation and Change in Abui. The Impact of Alor Malay on an Indigenous Language of Indonesia. LOT, Netherlands Graduate School, 2020.

[65] A. Stornaiuolo and E. E. Thomas, "Restorying as political action: Authoring resistance through youth media arts," Learning, Media and Technology, vol. 43, no. 4, pp. 345-358, 2018.

[66] B. R. Robin, "The power of digital storytelling to support teaching and learning," Digital Education Review, no. 30, pp. 17-29, 2016.

[67] W. Sulistyo and B. Kurniawan, "The Development of'JEGER'Application Using Android Platform as History Learning Media and Model," International Journal of Emerging Technologies in Learning (iJET), vol. 15, no. 7, pp. 110-122, 2020.

[68] I. Z. Ichsan, D. V. Sigit, M. Miarsyah, A. Ali, W. P. Arif, and T. A. Prayitno, "HOTS-AEP: Higher Order Thinking Skills from Elementary to Master Students in Environmental Learning," European Journal of Educational Research, vol. 8, no. 4, pp. 935-942, 2019.

[69] K. M. Enneking, G. R. Breitenstein, A. F. Coleman, J. H. Reeves, Y. Wang, and N. P. Grove, "The evaluation of a hybrid, general chemistry laboratory curriculum: Impact on students' cognitive, affective, and psychomotor learning," Journal of Chemical Education, vol. 96, no. 6, pp. 1058-1067, 2019.

[70] R. L. Lamb, L. Annetta, J. Firestone, and E. Etopio, "A meta-analysis with examination of moderators of student cognition, affect, and learning outcomes while using serious educational games, serious games, and simulations," Computers in Human Behavior, vol. 80, pp. 158-167, 2018.

[71] S. Marfu'ah, I. W. Djatmiko, and M. Khairudin, "Learning goals achievement of a teacher in professional development," Jurnal Pendidikan Teknologi dan Kejuruan, vol. 23, no. 3, pp. 295-303, 2017.

[72] A. I. Starčič, Ž. Turk, and M. Zajc, "Transforming Pedagogical Approaches Using Tangible User Interface Enabled Computer Assisted Learning," International Journal of Emerging Technologies in Learning, vol. 10, no. 6, 2015

[73] E. Kyndt, D. Gijbels, I. Grosemans, and V. Donche, "Teachers' everyday professional development: Mapping informal learning activities, antecedents, and learning outcomes," Review of educational research, vol. 86, no. 4, pp. 1111-1150, 2016

[74] O. Viberg, M. Hatakka, O. Bälter, and A. Mavroudi, "The current landscape of learning analytics in higher education," Computers in Human Behavior, vol. 89, pp. 98-110, 2018.

[75] K. D. Stiller and S. Schworm, "Game-based learning of the structure and functioning of body cells in a foreign language: effects on motivation, cognitive load, and performance," in Frontiers in Education, 2019, vol. 4, p. 18: Frontiers.
[76] B. S. Bloom, "Taxonomy of educational objectives," Handbook I : Cognitivs Domain., vol. 20, p. 24, 1956.

[77] J. Biggs, "Individual differences in study processes and the quality of learning outcomes," Higher education, vol. 8, no. 4, pp. 381-394, 1979.

[78] I. Gunawan, "Indonesian Curriculum 2013: Instructional management, obstacles faced by teachers in implementation and the way forward," in 3rd International Conference on Education and Training (ICET), 2017, pp. 56-63: Atlantis Press.

[79] S. J. Courey, P. Tappe, J. Siker, and P. LePage, "Improved lesson planning with universal design for learning (UDL)," Teacher Education

[80] R. J. Paxton and A. S. Marcus, "Film media in history teaching and learning," The Wiley International Handbook of History Teaching Learning. New York: Wiley-Blackwell, pp. 579-601, 2018.

[81] H. L. LaMarre and K. D. Landreville, "When is fiction as good as fact? Comparing the influence of documentary and historical reenactment films on engagement, affect, issue interest, and learning," Mass Communication Society, vol. 12, no. 4, pp. 537-555, 2009.

[82] A. S. Marcus and J. D. Stoddard, "The inconvenient truth about teaching history with documentary film: Strategies for presenting multiple perspectives and teaching controversial issues," The Social Studies, vol. 100, no. 6, pp. 279-284, 2009.

[83] D. A. Kenny, "A quasi-experimental approach to assessing treatment effects in the nonequivalent control group design," Psychological Bulletin, vol. 82, no. 3, p. 345,1975 .

[84] S. Valenzuela, "Unpacking the use of social media for protest behavior: The roles of information, opinion expression, and activism," American behavioral scientist, vol. 57, no. 7, pp. 920-942, 2013.

[85] C. S. Andreassen, S. Pallesen, and M. D. Griffiths, "The relationship between addictive use of social media, narcissism, and self-esteem: Findings from a large national survey," Addictive behaviors, vol. 64, pp. 287-293, 2017.

[86] J. M. Ferguson, "Queering Methodologies: Challenging Scientific Constraint in the Appreciation of Queer and Trans Subjects," Qualitative Report, vol. 18, p. 25, 2013.

[87] S. M. Al-Balushi and S. S. Al-Aamri, "The effect of environmental science projects on students' environmental knowledge and science attitudes," International Research in Geographical and Environmental Education, vol. 23, no. 3, pp. 213-227, 2014.

[88] R. Kabha, "Cognitive, Affective, Social and Cultural Aspects of Teaching and Learning in Media Studies," European Journal of Educational Research, vol. 8, no. 4, pp. 1287-1294, 2019.

[89] H. L. Sharma and L. Pooja, "Enhancing students' interest in English language viamultimedia presentation," International Journal of Applied Research, vol. 2, no. 1, pp. 275-281, 2016

[90] M. Ganapathy and S. A. Seetharam, "The Effects of Using Multimodal Approaches in Meaning-Making of 21st Century Literacy Texts among ESL Students in a Private School in Malaysia," Advances in Language and Literary Studies, vol. 7, no. 2, pp. 143-155, 2016.

[91] B. Olsen, Teaching what they learn, learning what they live: How teachers' personal histories shape their professional development. Routledge, 2015.

[92] A. S. Marcus, S. A. Metzger, R. J. Paxton, and J. D. Stoddard, Teaching history with film: Strategies for secondary social studies. Taylor \& Francis, 2018.

[93] J. Zipes, The enchanted screen: The unknown history of fairy-tale films. Routledge, 2011

[94] G. Shabiralyani, K. S. Hasan, N. Hamad, and N. Iqbal, "Impact of Visual Aids in Enhancing the Learning Process Case Research: District Dera Ghazi Khan," Journal of education and practice, vol. 6, no. 19, pp. 226233, 2015.

[95] M. Brunmair and T. Richter, "Similarity matters: A meta-analysis of interleaved learning and its moderators," Psychological bulletin, vol. 145 , no. 11, p. $1029,2019$.

\section{Creative Commons Attribution License 4.0 (Attribution 4.0 International, CC BY 4.0)}

This article is published under the terms of the Creative Commons Attribution License 4.0

https://creativecommons.org/licenses/by/4.0/deed.en_US 